\title{
Issues associated with planning, implementing, managing and operating public transport projects in Ireland
}

\author{
R. Byrne Murray ${ }^{1}$, M. Murphy ${ }^{1} \&$ A. Ahern ${ }^{2}$ \\ ${ }^{1}$ College of Engineering and Built Environment, \\ Dublin Institute of Technology, Ireland \\ ${ }^{2}$ School of Civil, Structural and Environmental Engineering, \\ University College Dublin, Ireland
}

\begin{abstract}
Whilst considering the context to which public transport is planned in Ireland and internationally, the research has been concerned with studying the methodology and the roles of key stakeholders for the planning, implementation, management and operation of public transport projects in order to gauge the efficiency and suitability of the Irish planning process in relation to our international counterparts The paper will present principal findings from structured interviews undertaken with key stakeholders involved in the Irish process and will provide a basis for debating the issues raised as a consequence of these interviews. Key issues raised include: 1) the possible complexity of the planning process in Ireland; 2) the role of political agendas in the decision making process; and 3) the governance and institutional arrangements for planning public transport projects in Ireland in contrast with other international countries.

Keywords: public transport planning, institutional arrangements, governance, political agendas, public transport decision making, planning process, Irish planning, transport planning issues, stakeholders, planning complexities.
\end{abstract}

\section{Introduction}

Whilst considering the context to which public transport is planned in Ireland and internationally, the research has been concerned with studying the 
methodology and the roles of key stakeholders for the planning, implementation, management and operation of public transport projects in Ireland in order to gauge the efficiency and suitability of the Irish planning process in relation to our international counterparts.

The aim of this paper is to present the issues raised as a consequence of structured interviews undertaken with key stakeholders involved in the Irish process and to provide a basis for debating these issues in order to gauge the appropriateness of this planning process.

The paper will also outline the problems such as perceived overuse of the private car by some international commentators and the need to promote public transport in accordance with European Commission policy. The role of planning in promoting sustainable transport as well as the need to evaluate best practice internationally will also be examined.

The context to which public transport is planned, operated and managed in Ireland will be presented along with current impact of this approach. Whilst considering the Irish context, the methodology adopted for developing a survey questionnaire and undertaking structured interviews with key stakeholders will be explained and results of the structured surveys will be presented and discussed.

Finally, conclusions will be drawn from the research and structured interviews, considering that further research is required to validate results.

\section{The problems: efficient urban mobility and the role of public transport and the private car}

Beirao and Sarsfield Cabral [1] have argued that the needs and demands of service users for more efficient urban mobility and the ease of accessibility to transport infrastructure as a result of a change in demographics has resulted in a higher dependence on public transport in recent years. Beirao and Sarsfield Cabral [1] along with the European Commission [2] have also suggested that this coupled with a change in lifestyle patterns and attitudes and behaviours towards public transport and private car usage and the negative impacts of traffic congestion and pollution in urban areas along with the growth of economies and investment opportunities has led policy makers and national governments to respond to these demands through the provision, promotion and enhancement of innovative concepts for the mobility of people by public transport.

The European Commission [3] state that congestion costs Europe approximately one per cent of Gross Domestic Product (GDP) every year. This trend has also been underpinned by a more environmentally conscious society and fluctuations in the prices of fuel for the private car. Several studies indicate that petrol prices have a positive effect on public transport use (Bresson et al. [4]; Matas [5]; Wang [6]). This drive for more accessible and efficient public transport systems has meant that policy makers, governments, transport planners and other relevant stakeholders have been faced with challenges to deliver more attractive transport infrastructure and services to users in urban and rural areas (OECD [7]). Banister [8] suggests that transport policies are developed to 
manage the social, environmental, and economic impacts that society's increased desire for mobility brings.

With this challenge in mind, "the Renewed Sustainable Development Strategy (hereinafter SDS) of the European Union defines a sustainable transport system as the one that 'meets society's economic, social and environmental needs whilst minimizing its undesirable impacts on the economy, society and the environment'. More specifically, the main 'undesirable impacts on the economy, society and the environment' caused by transport are: congestion, oil dependence, accidents, emissions of GHG and of other pollutants, noise, and land fragmentation caused by infrastructure" (European Commission [9]).

\subsection{The role of public transport planners and policy makers.}

Marsden and May [10] argue that the task, means and challenges of delivering sustainable public transport systems has been widely addressed internationally and these commentators have concluded that it is generally correlated to the democratic and institutional arrangements within a country or region and the legislative and regulatory boundaries of public transport planning as well as factors including the availability of resources and motivations of all relevant stakeholders. They have argued that the extent to which such arrangements currently appear to work is a function of the range of powers and the funding levels afforded to the coordinating organisation. The European Commission [11] has stated that in recent years, it has become quite obvious that transport can be affected, in both a positive and negative manner, by many disparate issues. "When attempting to produce a positive effect on public transport operations legislative and organisational measures can be brought into play". The Commission also argues that for such measures to be implemented there is a need to establish a framework for policy development and decision making. "Through a coherent framework, local and national governments, and also public transport operators, are able to consider, implement and evaluate legislative and organisational measures effectively".

Veeneman [12] proclaims that the roles that various stakeholders, both public and private, have vary throughout Europe, suggesting the absence of a shared optimal way to organize public transport or substantial differences in situations in cities. In Ireland, the planning and development of public transport projects must be taken through a detailed process involving government departments, government agencies, local authorities and other public and private stakeholders. The institutional arrangements in place in Ireland are mostly dependent upon factors including the type of service to be integrated into the system or network, the source of funding, the location of the proposed service and/or infrastructure, the tasks involved in the process, which are generally underpinned by regulation or other legislative boundaries, and the required levels of expertise so as to ensure appropriate delivery of the infrastructure and/or service.

Tasks that may be essential when planning a public transport system or service include technical feasibility studies, route selection, public consultation, economic appraisal, development of a business case, environmental assessment, detailed design, statutory approval procedures and public procurement. As this 
paper has stated, issues have been raised by stakeholders involved in the Irish process, as a consequence of structured interviews, and these issues relate to the roles of stakeholders and the tasks that need to be undertaken in the process.

\subsection{Evaluation of international best practice: Response of public transport planners and policy makers.}

When considering international best practice, and reflecting on comments made by Veeneman [12], the roles that various stakeholders, both public and private, have vary throughout Europe, suggesting the absence of a shared optimal way to organize public transport or substantial differences in situations in cities. The challenge that many policymakers face is understanding travel behaviour and trends. Beirao and Sarsfield Cabral [1] recognise that understanding travel behaviour and trends and the reasons for choosing one mode of transport over another is an essential issue. Travel behaviour is complex and it is necessary to understand the underlying patterns of travel behaviour.

According to Cullinane [13], in cities such as Hong Kong, public transport is plentiful and relatively inexpensive and car ownership and use is extremely low, with Cullinane arguing that good public transport can deter ownership in this case. Buehler and Pucher [14] suggest that even controlling for differences between countries in demographics, socio-economics, and land use, logistic regressions show that Germans are five times as likely as Americans to use public transport. "In Singapore a predetermined number of permits allowing car ownership are auctioned annually" and "in Tokyo, any person that wishes to own a car must first prove that they have off-street parking space available for its use" [11]. This implies that transport planners and policy makers have implemented controlled measures and policies to influence car usage and possibly encourage the use of public transport.

Moreover, Buehler and Pucher [14] have stated that public transport in Germany attracts a much broader cross-section of society and for a greater diversity of trip purposes. They suggest that the success of German public transport is due to a coordinated package of mutually supportive policies that include: (1) more and better service, (2) attractive fares and convenient ticketing, (3) full multimodal and regional integration, (4) high taxes and restrictions on car use, and (5) land-use policies that promote compact, mixed-use developments. They have also concluded that it is the integrated package of complementary policies that explains why public transport in Germany can compete so well with the private car, even among affluent households. "Conversely, it is the lack of complementary policies that explains the continuing struggle of public transport in the United States". This may suggest that there are contextual issues with the planning of public transport in the United States which may relate to the issues raised by Irish stakeholders involved in public transport in Ireland. 


\section{Irish context: public transport planning in Ireland}

Public transport in Ireland has changed significantly over the past seventy years. In 1945, Coras Iompar na hEireann (CIÉ) was established to oversee public transport provision in Ireland and provided about $80 \%$ of all public transport services (O'Riain [15]).

In 1964, the Minister of Local Government commissioned "The Dublin Region" report which was conducted by Myles Wright. At that time, Wright [16] recognised the urgent need for a coordinated system of transport and traffic policy throughout metropolitan Dublin, under a single direction. Wright predicted that the particular service requirements which public transport would be called upon to meet in the future would include the provision of local bus services for the carless, and services, for commuters, to central Dublin. Wright [16] predicted that there would be a likely decline in the use of public transport in Dublin city as car ownership would increase. He also predicted that there would be a strong and continuing demand for public transport along radial routes into Dublin city, but these may suffer from congestion on the roads.

Since 1987, CIÉ has comprised of three major operating subsidiaries: Iarnróid Éireann (Irish Rail), Bus Éireann (Irish Bus) and Bus Átha Cliath (Dublin Bus) (O’Riain [15]; Conroy [17]). Urban rail services within the Dublin area are provided principally through the DART (Dublin Area Rapid Transit) operations of Iarnróid Éireann, and the LUAS light rail initiated by the Railway Procurement Agency (RPA).

Although there are three operating subsidiaries, transport policy for Ireland (Republic) is exercised primarily through the government's Department of Transport, Tourism and Sport, covering all modes of public (and freight) transport. The National Transport Authority is a state body established under statute in 2009 (Dublin Transport Authority Act 2008 and Public Transport Regulation Act 2009) and the principal functions of the authority are to promote an integrated transport network nationally whilst also entering into contracts for the provision of public transport services and provide funding for specified bus and rail travel services that are considered necessary for economic and social reasons. The Authority is also responsible for preparing and regularly reviewing a transportation strategy for the Greater Dublin Area, promoting an integrated transport network and financing the construction of public transport infrastructure (National Transport Authority [18]).

More recently, the National Transport Authority prepared "Greater Dublin Area: Draft Transport Strategy (2011-2013) 2030 Vision" which discussed the Government's national ten year transport investment framework 'Transport 21' which was published in November 2005. It set out a $€ 34$ bn national investment framework for transport infrastructure nationally for the ten year period up to 2016, €16bn of which was to be spent on improving public transport infrastructure and services, primarily within the Greater Dublin Area. Transport 21 included major investments in the Greater Dublin Area public transport. Major public transport schemes included several new LUAS lines and extensions to other rail lines (National Transport Authority [19]). This draft strategy was 
still under consideration by the Department of Transport, Tourism and Sport as of February 2013 and many public transport projects outlined in Transport 21 have been postponed in light of the recent economic downturn in Ireland.

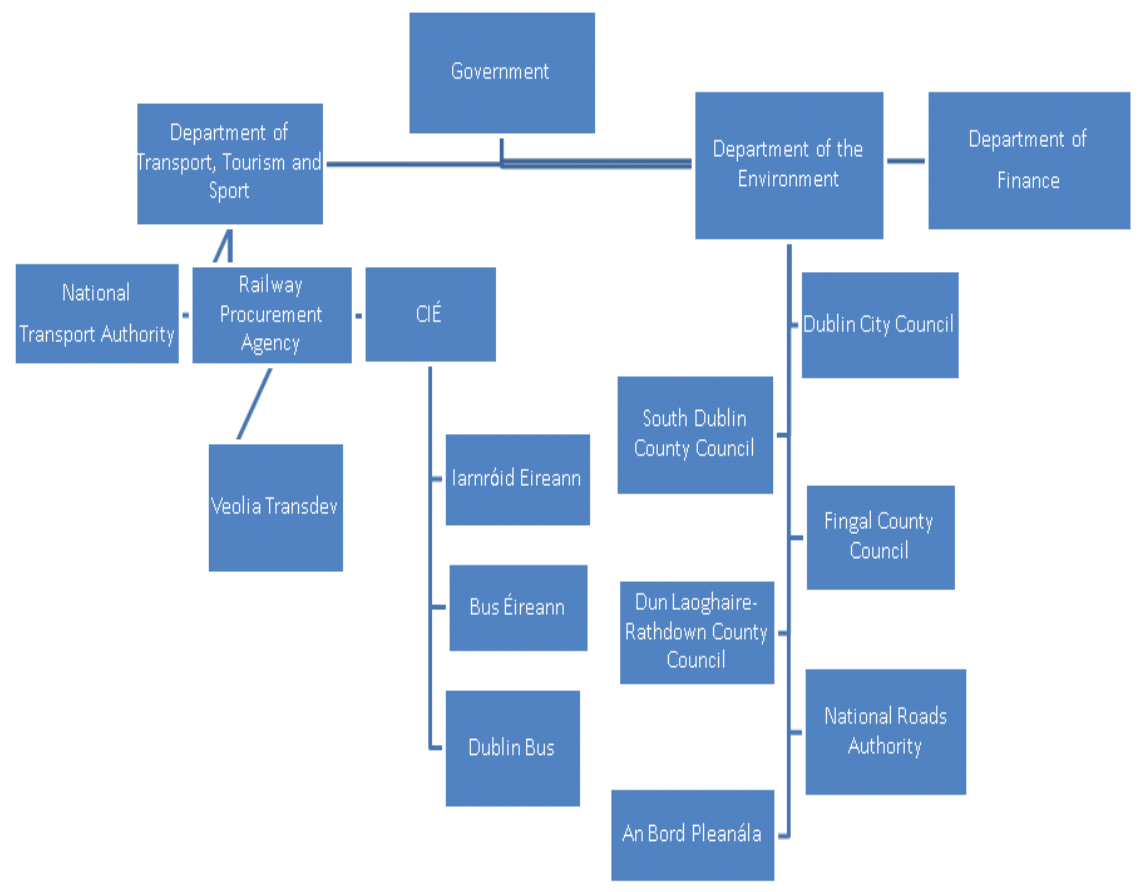

Figure 1: Interactions between public transport stakeholders in Ireland.

Local government also plays a role in terms of public transport planning and decision making. and differs from other public sector agencies (such as the National Transport Authority) as it is democratically elected and has therefore both a representative and an operational role, with responsibility for a range of services, including public transport services in the local area and drafting Local Area Development Plans (which considers public transport provisions in the area) (Department of the Environment, Community and Local Government [20]). Legislation stipulates that the strategy being drafted by the National Transport Authority should be "consistent with the Regional Planning Guidelines for the Greater Dublin Area, that it should prepared in such form or manner as may be directed by the Minister for Transport, and that in preparing the Strategy, the Authority should consult with and consider the views of a range of stakeholders and the wider public". Therefore, this implies that there should be interaction between Local Government and the National Transport Authorities in terms of public transport planning and policies (National Transport Authority [19]). There has also been other actors through the years in Ireland who have been involved in the planning of public transport and the decision making process. "An Bord 
Pleanala was established in 1977 under the Local Government (Planning and Development) Act, 1976 and is responsible for the determination of appeals and certain other matters and determination of applications for strategic infrastructure development including major road and rail cases. It is also responsible for dealing with proposals for the compulsory acquisition of land (for the provision of public transport infrastructure or otherwise) by local authorities and others under various enactments". For example, An Bord Pleanala deals with the application for a railway order by the Railway Procurement Agency, CIÉ or other person with the consent of the Railway Procurement Agency and is involved in the likes of the revocation of a railway order (An Bord Pleanala [21]).

Therefore, there are a number of actors currently involved in the planning and organising of public transport in Ireland and Figure 1 represents the interactions between some of these stakeholders.

Most of these key stakeholders engaged in the structured interviews for the purposes of the research.

\subsection{Impacts of current and future transport policy}

The European Commission [9] is of the view that the quality, accessibility and reliability of transport services will gain increasing importance in the coming years, inter alia due to the ageing of the population and the need to promote public transport. Attractive frequencies, comfort, easy access, reliability of services, and intermodal integration are the main characteristics of service quality. The availability of information over travelling time and routing alternatives is equally relevant to ensure seamless door-to-door mobility for passengers. This indicates the paradigm shift expected in terms of European citizens using public transport verses the private car.

Whilst considering these efforts by the European Union, the Central Statistics Office [22] in Ireland, reported from the 2011 Census that amongst public transport users, bus users fell from 114,956 to 91,676, a fall of 23,280 while train users were also down marginally from 54,942 to 52,749 . This may be related to the fact that the number of people commuting to work fell by 5 per cent from 1.79 million in 2006 to 1.70 million in 2011 . "The number of people driving to work fell by 12,995 while the percentage of commuters driving to work increased from 61.5 per cent in 2006 to 65.5 per cent in 2011. Car passengers showed the sharpest decline from 104,861 in 2006 to 69,164 in 2011, a drop of 34 per cent. When car commuters are combined with those workers who drove a van or lorry, 75 per cent of all workers were private vehicle users in 2011".

This indicates that there may be challenges for Irish policy makers involved in the planning, implementation, operation and management of public transport to address this decline in use and identification of the issues raised by key stakeholders (as a consequence of structured interviews) involved in this research may assist in addressing this decline and developing measures to promote and enhance the use of public transport, as encouraged by the European Commission. 


\section{Methodology}

Whilst considering the context to which public transport is planned in Ireland and abroad, the research has been concerned with studying the methodology and the roles of key stakeholders for the planning, implementation, management and operation of public transport projects in order to gauge the efficiency and suitability of the Irish planning process in relation to our international counterparts.

In order to gain an in depth understanding of the process and roles of stakeholders, survey questionnaires were developed and used as a qualitative means to conducting structured interviews with key stakeholders. Stakeholders (Irish and international) were identified on the basis of their intended and perceived legislative functions and relevant expertise, knowledge and experiences in the areas of planning, implementing, operating and managing public transport projects and associated infrastructure.

Stakeholders were then divided into two distinct categories:

- Category A: Government (or related) stakeholders;

- Category B: Scholars and other experts.

A survey questionnaire tailored for each category of stakeholder was developed and stakeholders from each category were asked to engage in the structured interviews. The sample size of survey respondents was 29 which included 12 respondents from Category A and 17 respondents from Category B. The aims of the structured interviews were to:

i. Gain a full understanding of the process (from each stakeholder's perspective - personal and/or organizational); and,

ii. Gain a full understanding of the roles of the specific stakeholder and their understanding of the role(s) of other stakeholders.

Each respondent was asked if they wished for their interview to be recorded and some respondents declined as it enabled them to discuss matters and issues more freely and in a more informal manner. Questions ranged from topics such as their role in the process to their view of the way in which public consultation is conducted in Ireland. Other questions related to their views regarding the reasons for delays in the Irish process in a historical sense and their perceptions regarding the flow of information between stakeholders and levels of cooperation. Respondents were also asked to discuss their views of international best practice and cities or countries that they deemed to be efficient and admirable in terms of planning, implementing, operating and managing public transport projects.

\section{Research results: issues raised as a consequence of comments made by survey respondents}

Following the completion of the structured interviews, a list of issues raised as a consequence of comments made by survey respondents was compiled. The comments raised broadly fitted into three categories of issues which relate to: 
A. Possible complexity of the process;

B. Political agendas;

C. Governance.

As a result of these findings, key research questions have been developed in relation to each category of issue:

A. Complexity of the process:

Is the process of planning and implementing public transport projects in Ireland overly complex and if so, what are the key factors causing this complexity?

B. Political agendas:

Are approvals for the initiation of public transport projects in Ireland influenced by political agendas and have there been unrealistic approaches taken by decision makers in the political sphere relating to government spending, forecasted demands for transport services; route selection, etc?

\section{Governance:}

Is there a lack of appropriate governance structures in Ireland and has this resulted in the misunderstanding of roles and responsibilities and the duplication of some roles and has this introduced a degree of opaqueness regarding decision making in Ireland for public transport infrastructure?

The research questions provide a basis for examining these issues in greater detail and also raised questions regarding the appropriateness of the manner in which public transport is planned, organised and operated in Ireland in contrast to other democratic countries. Lessons may be learnt from countries such as France who 55 per cent of stakeholders identified as being a country which can be admired in terms of its governance and institutional arrangements as well as the Netherlands whom 26 per cent of the stakeholders stated was admirable in relation to its governance and efficiencies. The international arena may also learn from the Irish situation in terms of the "do's and don'ts" of public transport policies and planning.

To summarise, this qualitative study has presented the context to the manner in which public transport is planned and organised in Ireland. The key stakeholders involved in the planning, implementation, management and operation of public transport projects in Ireland have been identified as well as the trends of public transport usage verses use of the private car. The key findings of the structured interviews undertaken with key stakeholders indicated that there are some issues with the manner in which public transport is organised and delivered. The comments raised broadly fitted into three categories of issues which relate to; A) possible complexity of the process and if the process of planning and implementing public transport projects in Ireland is overly complex and if so, what are the key factors causing this complexity?; B) political agendas and if there is a lack of appropriate governance structures in Ireland and has this resulted in the misunderstanding of roles and responsibilities and the duplication of some roles and has this introduced a degree of opaqueness regarding decision 
making in Ireland for public transport infrastructure?, and; C) governance and if there a lack of appropriate governance structures in Ireland and has this resulted in the misunderstanding of roles and responsibilities and the duplication of some roles and has this introduced a degree of opaqueness regarding decision making for public transport infrastructure? Furthermore, the attitudes of stakeholders and policy makers involved in the planning and organising of public transport should be as significant as the attitudes and behaviour of users. These issues raised by stakeholders in Ireland should be used as a basis for debating the appropriateness of how public transport is planned, implemented, managed and operated in Ireland and internationally.

\section{References}

[1] Beirao, G; Sarsfield Cabral J.A. Understanding attitudes towards public transport and private car: A qualitative study. Elsevier: Transport Policy. 14 (6): 478-489, 2007.

[2] European Commission, White Paper: Roadmap to a Single European Transport Area - Towards a competitive and resource efficient transport system. pp. 8-13, 2011.

[3] European Commission. White Paper: European transport policy for 2010: time to decide. pp. 8, 2001.

[4] Bresson, G., Dargay, J., Madre, J. L., and Pirotte, A. Economic and structural determinants of the demand for public transport: an analysis on a panel of French urban areas using shrinkage estimators. Transportation Research Part A: Policy and Practice, 38(4), 269-285, 2004.

[5] Matas, A. Políticas de transporte y congestión en áreas urbanas: un panorama. Urban Public Economics Review 1. pp. 63-91, 2004.

[6] Wang, J. Appraisal of factors influencing public transport patronage. Booz and Company, Auckland, New Zealand, (2011).

[7] OECD. Household behaviour and the environment. pp. 81, 2008.

[8] Banister, D. "Sustainable mobility". Built Environment. 26(3), pp. 175$186,2000$.

[9] European Commission, Commission staff working paper: Impact Assessment - Accompanying document to the White Paper. pp. 20, 28, 2011.

[10] Marsden, G. R., and May, A. D. Do institutional arrangements make a difference to transport policy and implementation? Lessons for Britain. Environment and Planning C: Government and Policy, 24(5), pp. 771-789 2006.

[11] European Commission: Directorate General for Transport. Transport Research - APAS - Public transport prioritization. pp. 60, 66, 1996.

[12] Veeneman, W. Mind the Gap - Bridging Theories and Practice for the Organisation of Metropolitan Public Transport. DUP Science, pp. 24, 2002. 
[13] Cullinane, S. The relationship between car ownership and public transport provision: a case study of Hong Kong. Elsevier: Transport Policy. 9 (1): pp.29-39, 2002.

[14] Buehler, R., and Pucher, J. Demand for Public Transport in Germany and the USA: An Analysis of Rider Characteristics. Transport Reviews, 32(5), pp. 541-567, 2012.

[15] O'Riain, Michéal. On the move: Córas Iompair Éireann 1945-1995. Gill and Macmillan, 1995.

[16] Wright, Myles. The Dublin Region: Advisory Regional Plan and Final Report. Dublin Stationary Office. pp. 144, 146. 1967.

[17] Conroy, J.C. A History of Railways in Ireland". Longmans Green and Co., 1928.

[18] National Transport Authority. http://www.nationaltransport.ie/about-us/. 2013.

[19] National Transport Authority. (2011). Greater Dublin Area: Draft Transport Strategy (2011-2030) - 2030 Vision. pp. 13-14, 2011.

[20] Department of the Environment, Community and Local Government. http://www.environ.ie/en/LocalGovernment/LocalGovernmentAdministrati on/ . 2013.

[21] An Bord Pleanala: Function of the Board. http://www.pleanala.ie/about/ function.htm. 2013

[22] Central Statistics Office. "This is Ireland - Highlights from Census 2011, Part 2". pp. 34, 2011. 